\title{
A description of the elusive, dissolving ecological capacity of Cummings's poetry
}

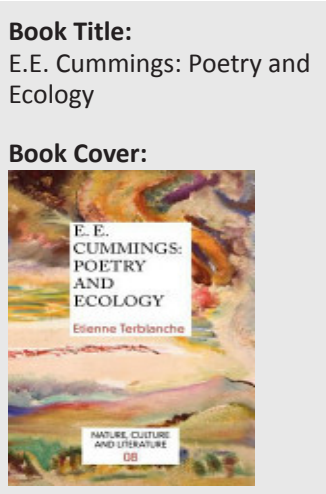

Author:

Etienne Terblanche

Publisher:

Rodopi, New York, 2012, 262

p., ZAR1305.00*

*Book price at time of review

ISBN:

978-90-420-3541-6

Reviewer:

Affiliation:

${ }^{1}$ Department of English,

Rhodes University,

South Africa

Review Title:

A description of the elusive,

dissolving ecological capacity

of Cummings's poetry

Email:

d.wylie@ru.ac.za

Postal address:

PO Box 94, Grahamstown

6410, South Africa

How to cite this book review:

Wylie, D., 2013, 'A

description of the elusive,

dissolving ecological capacity

of Cummings's poetry',

Literator 34(1), Art. \#418,

2 pages. http://dx.doi.

org/10.4102/lit.v34i1.418

\section{Copyright:}

(C) 2013. The Authors.

Licensee: AOSIS

OpenJournals. This work

is licensed under the

Creative Commons

Attribution License.

Read online:
In what I still regard as one of the finest books on global modernist poetry, The Truth of Poetry (1982), Michael Hamburger mentions E.E. Cummings only once, and that to remark on a certain misanthropy in the American experimenter's work. And in a more recent article on 'Ecology and Aesthetics' (2001:14), Allan Johnson claimed that Robinson Jeffers 'stands as the only Modernist to address ecological issues'.

In his book, the culmination of several years' work on Cummings, Etienne Terblanche sets out to rectify the two areas of neglect exemplified by these references: firstly, the general sidelining of Cummings in the modernist critical canon, which has habitually classified him as a 'minor' poet, or at best 'minor-major'; and secondly, the lack of attention paid to Cummings by ecologically orientated critics, or ecocriticism. In addition, Terblanche uses the case of Cummings to springboard an ecocritical approach to other modernist poets - particularly the 'high' modernists T.S. Eliot and Ezra Pound (with whom Cummings corresponded voluminously) - thus contesting an impression that the natural world has been uniformly excised from the anthropocentric, urbanised modernist mindset. This critical bias, Terblanche suggests, has been largely responsible for Cummings's neglect: a man who enthused with almost child-like vivacity and untrammelled immediacy about the pleasures of nature was bound to be scorned by an establishment that valorised intellectual detachment, irony and the so-called 'linguistic turn' away from the material world. Modernist poetry 'should epitomize a breach with Romanticism' (p. 20). A rather similar fate has arguably befallen Mary Oliver, whose determined enthusiasms are, like Cummings's, deeply congruent with Buddhist or Taoist approaches to the natural world and to the dispersal of the egoistic self.

Cummings's debt to Taoism (again, largely accessed via Pound) is a prominent thread throughout Terblanche's book, interwoven with the poet's intense attentiveness to the natural world, is an obvious subject for an ecocritical approach. Alongside Taoism's somewhat suspicious view of, and therefore highly economical use of, language, runs what has recently been termed the 'material/ ist turn' in ecocritical studies, by which words are conceived of, after all, having a preternaturally organic relationship with the objects they purport to describe. Cummings's famously playful but challenging reworking of grammar and punctuation, poetic shape and form in part enacts, and holds in creative tension, both these tendencies - as Terblanche shows with a number of dense but revealing close readings of individual poems.

Terblanche divides his book into four chapters on aspects of Cummings's ecological work, eschewing chronology for the conceptual:

1. Cummings's poetic status and his eco-logos

2. the rise of Cummings's ecological status

3. the scope of Cummings's poetic ecology

4. the manner and achievement of Cummings's poetic ecology.

As the breadth of these titles might indicate, they inevitably entail some overlap in content, and a certain blurring of focus. This is, however, a minor criticism of an energised and persuasive discussion. In the course of these chapters, Terblanche takes care to distinguish Cummings's work from various approaches of 'ecology' as opposed to 'environmentalism', tackles the tricky relationships between form (such as his modified sonnets) and fluidity of ecologically orientated content, and explores the influence of Taoist concepts, especially what he calls 'three-ness'. This is a kind of 'third space' or 'third voice' that transcends the binarism so beloved of Western philosophy - or at least that tradition of Western philosophy which critics, particularly ecocritics, love to set up as a straw man, ignoring almost equally powerful non-binarist traditions within Western thought, including, in Terblanche's view, much of modernist poetry itself.

Perhaps only in his deployment of this notion of 'three-ness' does Terblanche's discussion feel a little strained, especially in his fifth and final chapter, in which he tries to apply it to the work of Eliot and Pound. This is, illuminatingly, to make a start on incorporating an inevitable undertow 
of natural presences into criticism of even 'high' modernist poets. However, the attempt to commandeer them for this notional 'third voice', which rather vaguely 'relates itself to' ecological issues - 'ecology in the broad sense of an active completeness, wholeness and integrity of the poetic sign as well as ... those relationships that sustain the quality and sensitivity of human biological survival' (p. 230) - also feels unnecessarily forced. A certain imprecision creeps into many of these kinds of discussion, so that a reading of, say, love poems as somehow 'ecological', even in the total absence of natural-world elements, to my mind sometimes strains the concept of 'ecology' beyond its carrying capacity.

If Terblanche's language itself is not always the most mellifluous, there are times when his enthusiasm lifts his prose to the level of lyricism, and his detailed expositions to the point of the startlingly insightful. It is particularly gratifying to see a scholar from South Africa, where ecocriticism remains thinly practised and imperfectly theorised, contributing so substantial and considered a volume, ably filling an astonishing lacuna in global scholarship. He has taken on a difficult task, 'to describe this elusive, dissolving ecological capacity' of Cummings's poetry, and unabashedly to call for a new direction in scholarship itself:

If [Cummings's] transgressions of semiotic boundaries allow him or his reader to transcend them, along with signs, so as to enter a renewed awareness of nature's 'magic', then so be it - modernism has never shied away from this kind of transcendence, and I believe this recognition will become clearer and clearer in modernist studies yet to come. (p. 56)

\section{References}

Johnson, A., 2001, 'Ecology and Aesthetics', Interdisciplinary Studies in Literature and Environment 8(2), 13-38. http://dx.doi.org/10.1093/isle/8.2.13 